\title{
Three new species of the genus Thinodromus Kraatz, 1857 from Indonesia and the Philippines (Coleoptera: Staphylinidae: Oxytelinae)
}

\author{
Три новых вида рода Thinodromus Kraatz, 1857 из Индонезии и \\ Филиппин (Coleoptera: Staphylinidae: Oxytelinae)
}

\author{
M.Yu. Gildenkov \\ М.Ю. Гильденков
}

Smolensk State University, Przhevalsky str. 4, Smolensk 214000, Russia. E-mail: mgildenkov@mail.ru
Смоленский государственный университет, ул. Пржевальского 4, Смоленск 214000, Россия.

KEY WORDS: Coleoptera, Staphylinidae, Thinodromus, new species, Oriental region, Indonesia, Philippines. КЛЮЧЕВЫЕ СЛОВА: Coleoptera, Staphylinidae, Thinodromus, новые виды, Восточная биогеографическая область, Индонезия, Филиппины.

ABSTRACT. Three new species of the genus Thinodromus are described: Thinodromus (s.str.) makarovi, sp.n. from Java and Sumatra; Thinodromus (s.str.) coronatus, sp.n. and Thinodromus (s.str.) shavrini, sp.n. from the Philippines.

РЕЗЮМЕ. Описываются три новых вида рода Thinodromus: Thinodromus (s.str.) makarovi, sp.n. c Явы и Суматры; Thinodromus (s.str.) coronatus, sp.n. и Thinodromus (s.str.) shavrini, sp.n. с Филиппин.

\section{Introduction}

So far, only three species of the genus Thinodromus Kraatz, 1857 were known from this part of the Oriental biogeographic region [Herman, 2001; Gildenkov, 2017, 2018a, b, 2019a, b; Makranczy, 2006, 2014, 2016; Schülke, Smetana, 2015]. Thinodromus (s. str.) sumatrensis (Bernhauer, 1915) is described from Sumatra, and is now also known from Bali [Gildenkov, 2017]. Thinodromus (s. str.) unipustulatus (Cameron, 1941) is described from the island of Luzon, and is now also known from other Philippine islands — Mindoro and Negros [Gildenkov, 2017]. Both of these species belong [Gildenkov, 2017] to the «lunatus» group. The third species, Thinodromus arcitenens (Fauvel, 1905), has been described from Java and, in our opinion [Gildenkov, 2015], is much closer to the species of genus Carpelimus Leach, 1819 of the subgenus Bucephalinus Koch, 1934, as evidenced by [Makranczy, 2014] structural features of the body (developed temples, shape of impressions on pronotum disk) and aedeagus structure.

The three species described in this work do not belong to the «lunatus» group or other known species group of Thinodromus.
This paper is based on the specimens deposited in the following collections: $\mathrm{cMG}$ - private collection of M. Gildenkov (Smolensk, Russia); DUISB Daugavpils University Institute of Systematic Biology (Latvia); MHNG - Museum d'Histoire Naturelle Geneva (Switzerland); NHMW - Naturhistorisches Museum Wien (Austria). In the present study, standard methods were used for the taxonomic research of insects; the preparations were made on an MBS-10 binocular microscope. The genital preparations were processed using $10 \% \mathrm{KOH}$ and then fixed in euparal. In the descriptions and diagnoses giving the length to width ratio for the head, pronotum, and elytra, the following standard units were used: 7 standard units $=0.1 \mathrm{~mm}$; thus, 1 standard unit constitutes about $0.0143 \mathrm{~mm}$. Photographs were taken with a Canon EOS 5D Mark III camera and a Canon MP-E $65 \mathrm{~mm}$ objective using the extended focus technology. The distributional maps were created using MapCreator 2.0 software.

Thinodromus (s.str.) coronatus Gildenkov, sp.n. Figs 1, 4-6.

MATERIAL. Holotype, $O^{7}$, Philippines, Negros Island: with labels "PHILIPP. 16.III.1994 Negros occ, Mambucal Seven Falls, ca 900m leg. Schödl (2)" (NHMW). Paratypes: $20^{7} 0^{\top}, 1$ 우 “PHILIPP. 16.III.1994 Negros occ, Mambucal Seven Falls, ca 900m leg. Schödl (2)" (NHMW; $\left.10^{\prime}-\mathrm{cMG}\right)$; 3 우, 1 ex. "PHIL.: Negros 1994 Mt. Canlaon, ca. 900m Mambucal, 16.3. leg. Zettel (39d)" (NHMW; 19 - cMG); 19 "PHILIPP.: Negros isl. Mambucal 12.2.1994 leg. Seyfert" (NHMW); 1 우 "Philippines Palawan central, along Tarabanan river, NE San Rafael, ca 30m, 7.XII.1995, Kodada \& Rigova lgt." (MHNG); 1 우 "Philippines Luzon: Lagunas, Los Banos, vegetation debris near small river, 28.XI.1995 J. Kodada \& B. Rigova lgt.” (MHNG).

DESCRIPTION (holotype). Length $2.7 \mathrm{~mm}$. Colouration brown, legs, last two segments of antennas and apex of elytra yellow-brown. Integument are quite shiny, body with fairly long light-coloured seta.

How to cite this article: Gildenkov M.Yu. 2020. Three new species of the genus Thinodromus Kraatz, 1857 from Indonesia and the Philippines (Coleoptera: Staphylinidae: Oxytelinae) // Russian Entomol. J. Vol.29. No.2. P.148152. doi: 10.15298/rusentj.29.2.04 
Head transverse, with a wide base, ratio of its length (from posterior margin of head to anterior margin of clypeus) to maximum width about 23:33. Neck constriction prominent. Eyes large, convex, occupying almost entire lateral side of head; temples almost indistinct, the head has the largest width in the eye area (Fig. 1). Head surface with clearly, rather finely and dense punctation. Diameter of punctures is about 1.5 times smaller than the eye facet. Distances between punctures significantly smaller than their diameter, interspaces smooth, shining (Fig. 1). Antennae long, with lengths of all antennal segments noticeably or significantly longer than their width (Fig. 1).

Pronotum heart-shaped, reaches its greatest width after about $2 / 3$ of the length measured from the base, then narrowed (Fig. 1). Ratio of pronotum length to its maximum width is about 28:36. Surface of pronotum with clearly, rather finely and dense punctation. Diameter of punctures about 1.5 times smaller than the eye facet. Distances between punctures are significantly smaller than their diameter, interspaces smooth, shining (Fig. 1). Base of pronotal disc with distinct horseshoe-shaped depression (Fig. 1); central part of disc with 2 symmetrical distinct weakly developed oval depressions.

Ratio of length of elytra to their combined width about 46:54. Elytra with clearly, rather finely and dense punctation.
Diameter of punctures dots is approximately equal to eye facet. Distances between punctures significantly smaller than their diameter, interspaces smooth, shining (Fig. 1).

Abdomen with fine and sparse punctation, shining.

Aedeagus of characteristic structure, with a peculiar form of paramers (Figs 4-5).

Female. Sexual dimorphism is absent, female morphologically similar to male. Spermatheca of characteristic structure (Fig. 6)

COMPARATIVE REMARKS. The species is distinguished by its small size, clear puncturation of the body surface and light coloring of the apex of the elytra. Reliably different in the structure of the aedeagus, especially in the form of parameres (Figs 4-5).

DISTRIBUTION. Philippines (Fig. 13).

ETYMOLOGY. From Latin "coronatus" (crowned); the name refers to the structure of parameres.

Thinodromus (s.str.) makarovi Gildenkov, sp.n. Figs 2, 7-9.

MATERIAL. Holotype, $\sigma^{7}$, Indonesia, West Java: with labels "INDONESIA: W Java Gn. Salak, $8 \mathrm{~km}$ S Bogor Sungai Ciapus, ca 800m lg. Schuh 17.8. 1994" (NHMW). Paratypes: $30^{7} 0^{7}$, 1 ㅇ "INDO-

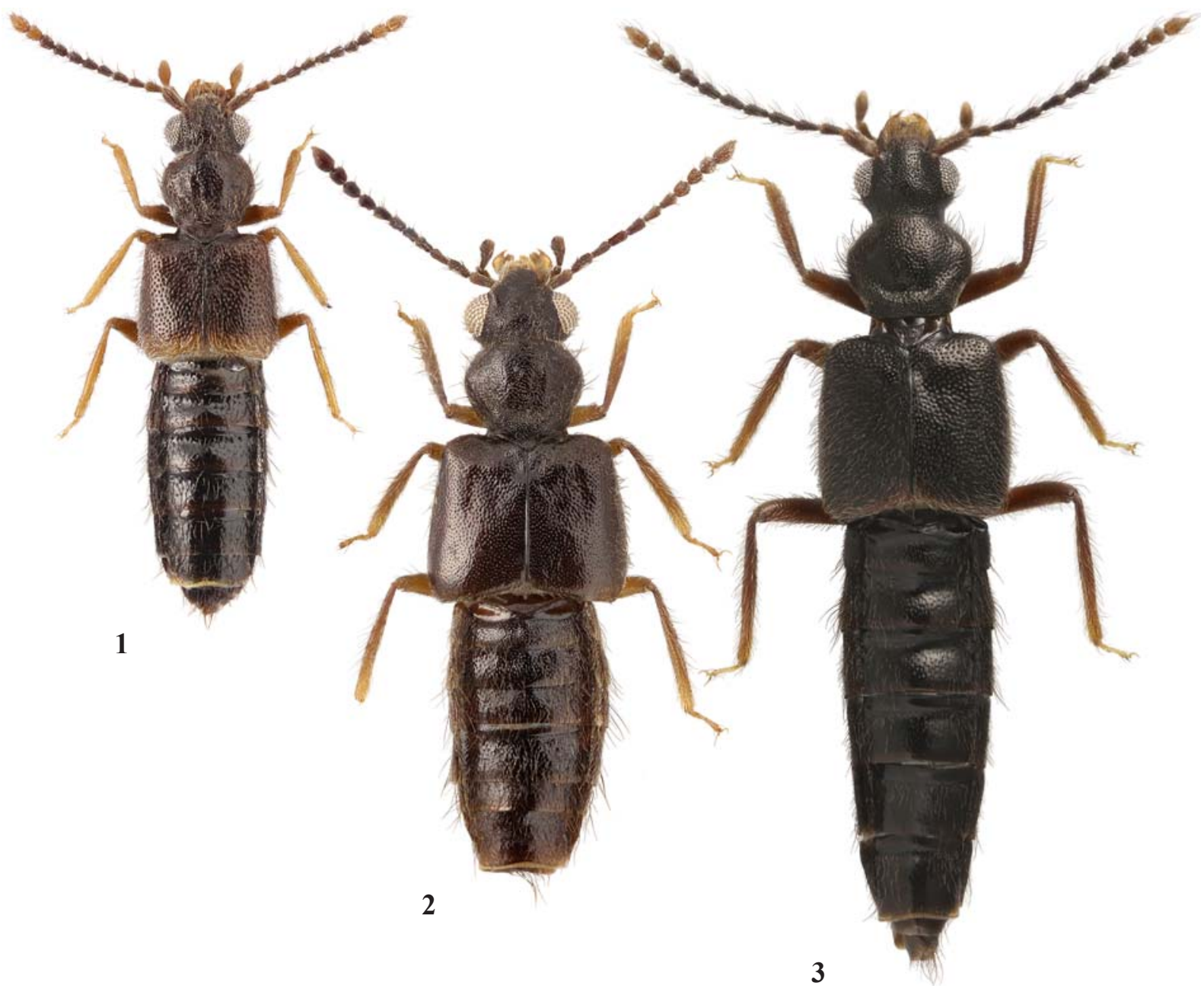

Figs 1-3. Thinodromus spp., holotypes, males, dorsal view: 1 - Thinodromus (s. str.) coronatus, sp.n.; 2 - Thinodromus (s. str.) makarovi, sp.n.; 3 - Thinodromus (s. str.) shavrini, sp.n.

Рис. 1-3. Thinodromus spр., голотипы, самцы, сверху: 1 - Thinodromus (s. str.) coronatus, sp.n.; 2 — Thinodromus (s. str.) makarovi, sp.n.; 3 - Thinodromus (s. str.) shavrini, sp.n. 
NESIA: W Java Gn. Salak, 8km S Bogor Sungai Ciapus, ca 800m lg. Schuh 17.8. 1994" (NHMW; $\left.10^{7}-\mathrm{cMG}\right) ; 2 \sigma^{7} \sigma^{7}, 1$ 웅, Indonesia, West Sumatra: with labels "INDONESIEN 1991 (28) W-Sumatra, W Danau di Atas 70 km SE Padang, leg. Jäch 24.2" (NHMW); 407 $\sigma^{7}$,
5 o, 5 ex., Indonesia, North Sumatra: with labels "SUMATRA ACEH Ketambe 7.-17.X.> <INDONESIA 1991, leg. Barries" (NHMW; 10", 1, 1 ex. - cMG); 1, 2 ex. "SUMATRA, Aceh Kutacane. Ketambe 7.-19.10.1991, 400m, leg. Barries” (NHMW).
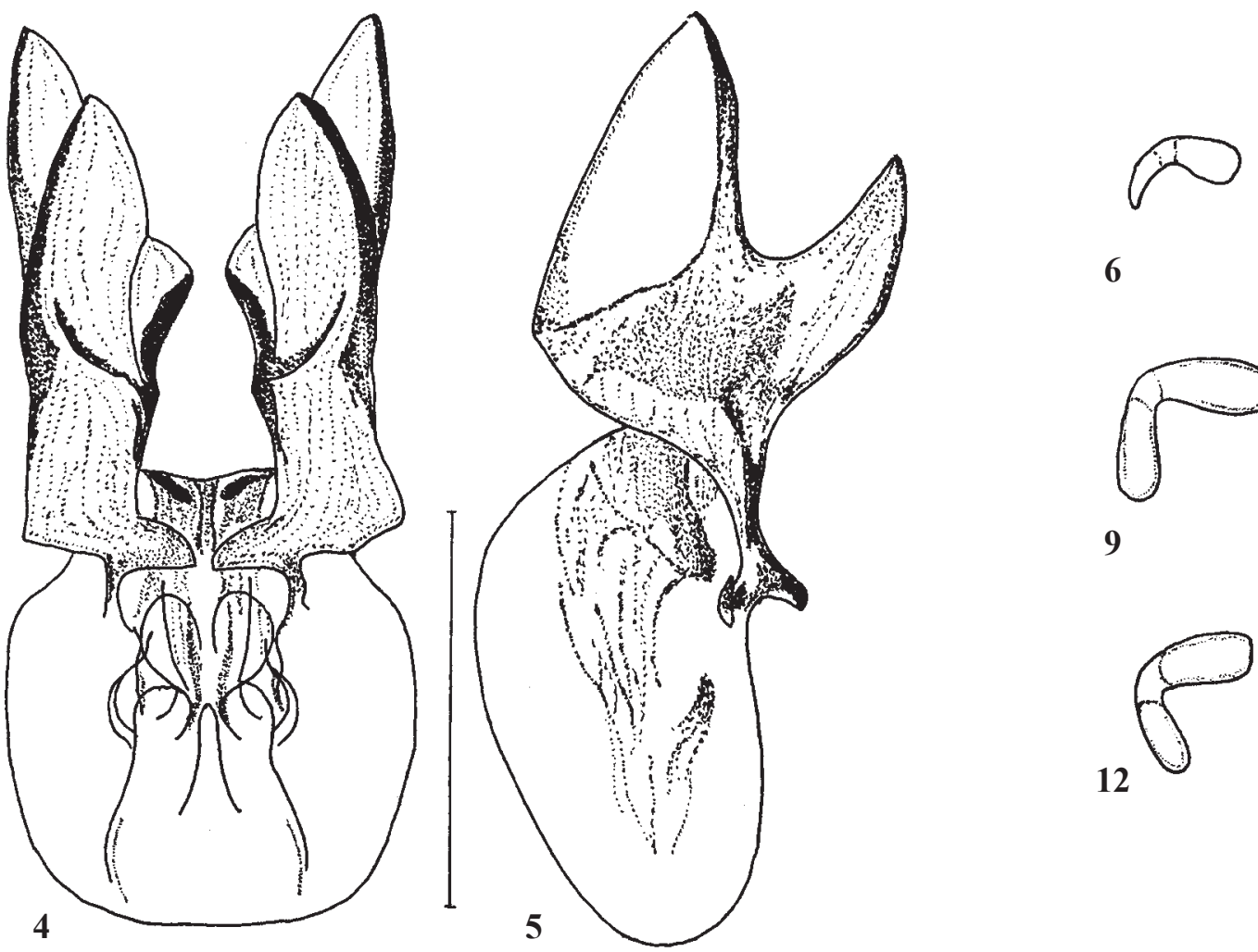

6

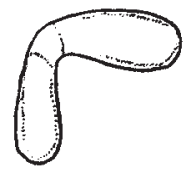

9
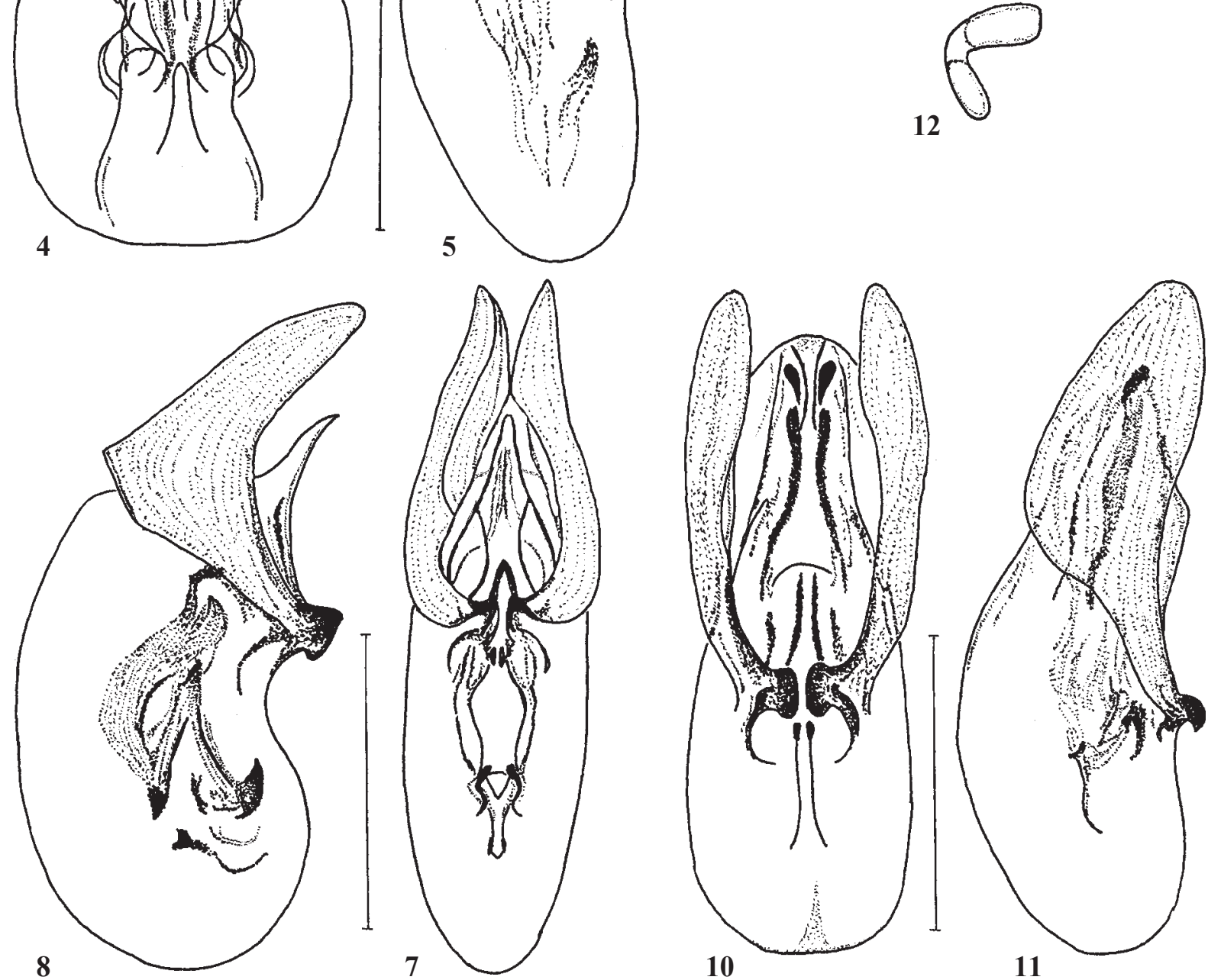

Figs 4-12. Genitalia of Thinodromus: 4-6 - T. coronatus, sp.n.; 7-9 - T. makarovi, sp.n.; 10-12 - T. shavrini, sp.n.; 4, 7, $10-$ aedeagus, ventral view (holotypes); 5, 8, 11 - aedeagus, lateral view (holotypes); 6, 9, 12 - spermatheca (paratypes). Scale bars: $0.25 \mathrm{~mm}$.

Рис. 4-12. Гениталии Thinodromus: 4-6 - T. coronatus, sp.n.; 7-9 - T. makarovi, sp.n.; 10-12 - T. shavrini, sp.n.; 4, 7, $10-$ эдеагус, снизу (голотипы); 5, 8, 11- эдеагус, сбоку (голотипы); 6, 9, 12 - сперматека (паратипы). Масштаб: 0,25 мм. 
DESCRIPTION (holotype). Length $3.3 \mathrm{~mm}$. Colouration brown, legs light-brown. Integument slightly shining, body with short, light-coloured seta. Some specimens are blackbrown, legs and antennas are brown.

Head transverse, with a wide base, ratio of its length (from posterior margin of head to anterior margin of clypeus) to maximum width is about $28: 43$. Neck constriction prominent. Eyes large, convex, occupying almost entire lateral side of head; temples almost indistinct, the head has the largest width in the eye area (Fig. 2). Head surface with rather clearly, highly finely and dense punctation. The diameter of the punctures is more than 5 times smaller than the diameter of the eye facet. Distances between punctures significantly smaller than their diameter, interspaces smooth, slightly shining (Fig. 2). Antennae rather long, antennal segments 1-8 elongated; segments 9-10 are about as long as wide; segment 11 elongated, conical (Fig. 2).

Pronotum heart-shaped, reaches its greatest width after about $2 / 3$ of the length measured from the base, then narrowed (Fig. 2). Ratio of pronotum length to its maximum width about 37:46. Surface of pronotum with rather clearly, finely and dense punctation. The diameter of the punctures is approximately 5 times smaller than the diameter of the eye facet. The distance between punctures is significantly smaller than their diameter, interspaces smooth, slightly shining (Fig. $2)$. Base of pronotal disc with distinct horseshoe-shaped depression (Fig. 2); central part of disc with 2 symmetrical distinct weakly developed oval depressions.

Ratio of length of elytra to their combined width about 65:76. Elytra with rather clearly, finely and dense punctation. The diameter of the punctures is about 4 times smaller than the diameter of the eye facet. Distance between punctures are a little smaller than their diameter, interspaces smooth, shining (Fig. 2).

Abdomen with fine and dense punctation, shining.

Aedeagus of characteristic structure (Figs 7-8).

Female. Sexual dimorphism is absent, female morphologically similar to male. Spermatheca of characteristic structure (Fig. 9).

COMPARATIVE REMARKS. The species is distinguished by large sizes, well- developed eyes, and distinct, fine, and dense punctation of the body surface. Reliably different in the structure of the aedeagus (Figs 7-8).

DISTRIBUTION. Indonesia: Java, Sumatra (Fig. 14).

ETYMOLOGY. The species is named after Kirill Vladimirovich Makarov, a well-known expert in the biology and taxonomy of Coleoptera.

13

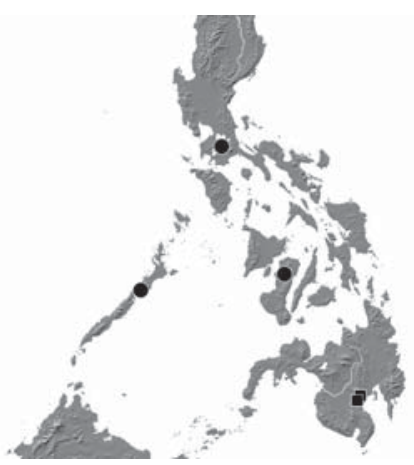

\section{Thinodromus (s.str.) shavrini Gildenkov, sp.n.}

$$
\text { Figs 3, 10-12. }
$$

MATERIAL. Holotype, ơ, Philippines, Mindanao Island: with labels "PHILIPPINES: Mindanao, Davao prov., Mt. Talomo (Mts. Apo) $1200-1300 \mathrm{~m} 7^{\circ} 04^{\prime} 40.9^{\prime \prime} \mathrm{N} 125^{\circ} 29^{\prime} 02.3^{\prime \prime} \mathrm{E}, 27-28.04 .2019$, Shavrin A.V. leg." (DUISB). Paratypes: $30^{7} 0^{7}, 2+9,2$ ex. "PHILIPPINES: Mindanao, Davao prov., Mt. Talomo (Mts. Apo) 1200-1300 $\mathrm{m} 7^{\circ} 04^{\prime} 40.9^{\prime} \mathrm{N} 125^{\circ} 29^{\prime} 02.3^{\prime \prime} \mathrm{E}, 27-28.04 .2019$, Shavrin A.V. leg." (DUISB; $10^{7}, 1$ ex. - cMG); $10^{7}$ "PHILIPPINES: Mindanao, Davao prov., Mt. Talomo (Mts. Apo), Gatigan, 800-1000 m 7001'22.0' $\mathrm{N}$ $125^{\circ} 22^{\prime} 30.5^{\prime \prime}$, 29.4-01.05.2019, Shavrin A.V. leg." (DUISB).

DESCRIPTION (holotype). Length $3.9 \mathrm{~mm}$. Colouration dark-brown, legs, 1st, 2nd and 9-11th segments of antennas and apex of elytra brown. Integument slightly shining, body with fairly long light-coloured seta.

Head transverse, with a wide base, ratio of its length (from posterior margin of head to anterior margin of clypeus) to maximum width is about 27:40. Neck constriction prominent. Eyes large, convex, occupying almost entire lateral side of head; eye diameter in dorsal view is about 3.5 times as long as temple length (Fig. 3). Head surface with clearly, finely and dense punctation. The diameter of the punctures is about 1.5 times smaller than the diameter of the eye facet. Distance between punctures is much smaller than their diameter, interspaces smooth, slightly shining (Fig. 3). Antennae long, with lengths of all antennal segments noticeably or significantly longer than their width (Fig. 3).

Pronotum heart-shaped, reaches its greatest width after about $2 / 3$ of its length measured from the base, then narrowed (Fig. 3). Ratio of pronotum length to its maximum width about 40:47. Surface of pronotum with clearly, finely and dense punctation. Diameter of punctures is slightly smaller than the diameter of an eye facet. Distance between punctures is much smaller than their diameter, interspaces smooth, slightly shining (Fig. 3). Base of pronotal disc with distinct horseshoeshaped depression (Fig. 3); central part of disc with 2 symmetrical distinct weakly developed oval depressions.

Ratio of length of elytra to their combined width is about 68:73. Elytra with clearly, finely and dense punctation. Diameter of punctures is slightly more than the diameter of an eye facet. Distance between punctures is much smaller than their diameter, interspaces smooth, slightly shining (Fig. 3).

Abdomen with fine and dense punctation, shining. Aedeagus of characteristic structure (Figs 10-11).

Female. Sexual dimorphism is absent, female morphologically similar to male. Spermatheca of characteristic structure (Fig. 12).

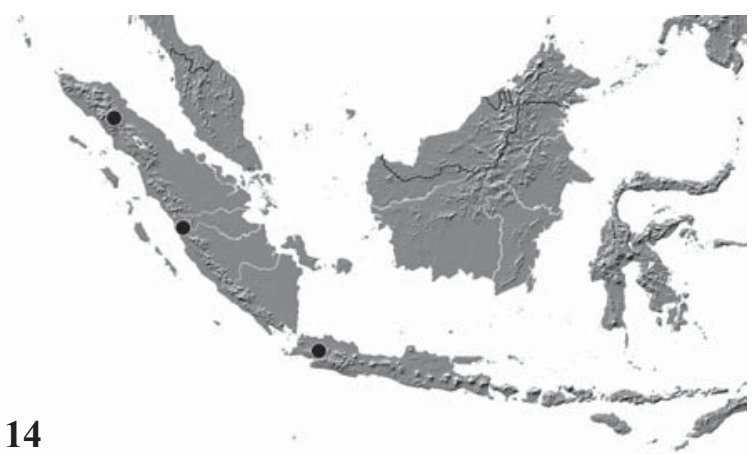

Figs 13-14. Distribution of Thinodromus: 13 - T. coronatus, sp.n. (black circles) and T. shavrini, sp.n. (black squares) in Philippines; 14 - T. makarovi, sp.n. in Indonesia.

Рис. 13-14. Распространение Thinodromus: 13 - T. coronatus, sp.n. (черные круги) и T. shavrini, sp.n. (черные квадраты) на Филиппинах; $14-$ T. makarovi, sp.n. в Индонезии. 
COMPARATIVE REMARKS. The species is distinguished by large sizes, a narrow body with a small head, clear, fine and dense punctation of the surface of the body. Reliably different in the structure of the aedeagus (Figs 10-11).

DISTRIBUTION. Philippines (Fig. 13).

ETYMOLOGY. The species is named after Alexey Valeryevich Shavrin, a well-known expert in the biology and taxonomy of Coleoptera, who collected the type series.

Acknowledgements. The author wishes to thank all colleagues for making material available for study: Alexey Shavrin (DUISB); Giulio Cuccodoro (MHNG) and Harald Schillhammer (NHMW). I also thank Kirill Makarov for taking the photos (Moscow Pedagogical State University, Russia).

\section{References}

Bernhauer M. 1915. Neue Staphyliniden aus Java und Sumatra // Tijdschrift voor Entomologie. Vol.58. P.213-243.

Cameron M. 1941. New species of Staphylinidae (Col.) from the Philippines // The Annals and Magazine of Natural History. Vol.11. No.7. P.430-447.

Fauvel A. 1905. Staphylinides de Java, recueillies par M. le Dr. K. Kraepelin et M. le Dr. Koningsberger en 1904 // Mitteilungen aus dem Naturhistorischen Museum in Hamburg. Bd.22. P.7586

Herman L.H. 2001. Catalog of the Staphylinidae (Insecta: Coleoptera). 1785 to the end of the second Millennium. // Bulletin of the American Museum of Natural History. Vol.265. No.3. P.1759-1776.

Gildenkov M.Yu. 2015. [Fauna of Carpelimus of the Old World (Coleoptera: Staphylinidae)]. Smolensk: SmolSU. 414 pp. [In Russian, with English summary]
Gildenkov M.Yu. 2017. [A review of the Thinodromus lunatus species-group (Coleoptera, Staphylinidae)] // Zoologicheskii Zhurnal. Vol.96. No.10. P.1165-1180 [in Russian; English translation: Entomological Review. 2017. Vol.97. No.8. P.1089$1105]$.

Gildenkov M.Yu. 2018a. A new species of the genus Thinodromus Kraatz, 1857 (Coleoptera: Staphylinidae: Oxytelinae) from China // Far Eastern Entomologist. No.356. P.17-20.

Gildenkov M.Yu. 2018b. [Six new species of the genus Thinodromus Kraatz 1857 close to Thinodromus (Amisammus) ripicola (Cameron 1941) (Coleoptera, Staphylinidae, Oxytelinae)] // Zoologicheskii Zhurnal. Vol.97. No.11. P.1363-1373 [in Russian; English translation: Entomological Review. 2018. Vol.98. No.8. P.1113-1123].

Gildenkov M.Yu. 2019a. New species of the Subgenus Thinodromus Kraatz, 1857 (Coleoptera: Staphylinidae: Oxytelinae), from India and Nepal // Far Eastern Entomologist. No.381. P.15-20.

Gildenkov M.Yu. 2019b. [Three new species of the Thinodromus arcuatus group, genus Thinodromus Kraatz, 1857 (Coleoptera, Staphylinidae, Oxytelinae), from the Oriental region] // Zoologicheskii Zhurnal. Vol.98. No.11. P.1205-1212 [in Russian; English translation: Entomological Review. 2019. Vol.99. No.8. P.1197-1204].

Makranczy G. 2006. Systematics and phylogenetic relationships of the genera in the Carpelimus group (Coleoptera: Staphylinidae: Oxytelinae) // Annales historico-naturales Musei nationalis hungarici. Vol.98. P.29-120.

Makranczy G. 2014. Review of the Thinodromus circulus species group (Coleoptera: Staphylinidae: Oxytelinae) // Acta Entomologica Musei Nationalis Pragae. Vol.54. No.2. P.539-554.

Makranczy G. 2016. Typological problems in East Palaearctic Thinodromus Kraatz, 1857 (Coleoptera: Staphylinidae: Oxytelinae) // Koleopterologische Rundschau. Vol.86. P.153-169.

Schülke M., Smetana A. 2015. Oxytelinae // I. Löbl, D. Löbl (Eds) Catalogue of Palaearctic Coleoptera. Vol.1 (Hydrophiloidea Staphylinoidea). Leiden-Boston: Brill. P.793-795. 